Beyond the Ivory Tower 



\section{Derek Bok}

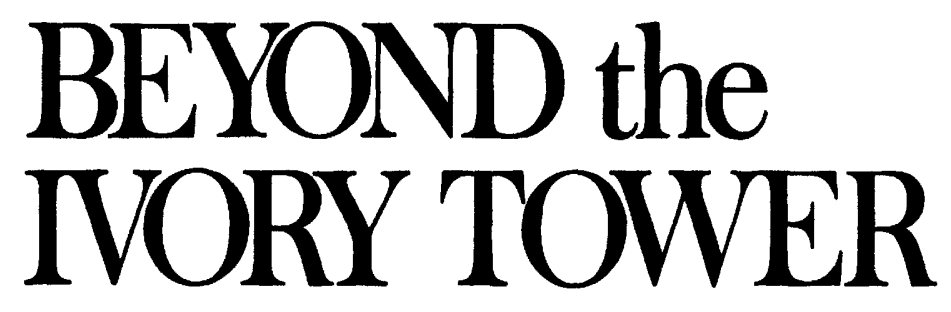

Social Responsibilities of the Modern University

Harvard University Press

Cambridge, Massachusetts, and London, England 
Copyright $\odot 1982$ by the President and Fellows of Harvard College All rights reserved

Printed in the United States of America

This book has been digitally reprinted. The content remains identical to that of previous printings.

Library of Congress Cataloging in Publication Data

Bok, Derek Curtis.

Beyond the ivory tower.

Includes index.

1. Education, Higher-United States-Aims and objectives. 2. Academic freedom-United States.

I. Title.

LB2331.72.B64 378'.01 '0973

$81-20278$

ISBN 0-674-06899-8 (cloth)

AACR2

ISBN 0-674-06898-X (paper) 
FOR MY MOTHER 
